\title{
LAS JÁCARAS A LO DIVINO: UN INÉDITO DE CÁNCER Y VELASCO
}

JuAN C. GONZÁlez MAYA

Universidad de las Islas Baleares

\section{RESUMEN}

El presente trabajo saca a la luz una composición inédita de Jerónimo de Cáncer y Velasco, ilustre poeta del siglo XVII. Encontrada en un manuscrito de la Hispanic Society de Nueva York es una excelente muestra del estilo del autor, especialista en los juegos del lenguaje, sobre todo en la disemia. Pertenece al género de lo que se ha dado en denominar «jácaras a lo divino», del que Cáncer fue un auténtico especialista. Influido por las jácaras de Quevedo, el poeta aprovecha el lenguaje de la germanía como instrumento de diversión a costa de un desconocido Francisco de Asís, convertido en un auténtico truhán del siglo XVII.

Palabras clave: Francisco de Asís, Cáncer y Velasco, jácaras a lo divino, romances, germanía, disemia.

\section{JÁCARAS A LO DIVINO: AN UNPUBLISHED WORK BY CÁNCER Y VELASCO}

\section{ABSTRACT}

This essay reveals an unpublished composition by Jerónimo de Cáncer y Velasco, illustrious poet from the XVIIth Century. Found in a manuscript of the Hispanic Society of New York, it's an excellent example of the author's style, specialist in plays on words. This work pertains to the genre called "jácaras" referred to the divine in which Cáncer was a real expert. Influenced by Quevedo's "jácaras" the poet makes good use of the underworld parlance as an amusement instrument with the unknown Francisco de Asís transformed into a rogue from the XVIIth Century.

Key words: Francisco de Asís, Cáncer y Velasco, "jácaras" to the divine, ballads, underworld parlance, double meaning words.

La figura de Jerónimo de Cáncer y Velasco pertenece a ese grupo de escritores cuya notoriedad y popularidad fueron considerables entre sus contemporáneos, pero que el tiempo ha sepultado. No debido a su calidad literaria, desde luego, sino a otras consideraciones que han jugado a favor de otros escritores con más fama, suerte o talento. Algunos calificativos de ingenio menor o de segunda fila con los que a veces ha sido censurado despectiva- 
mente parecen excesivos a la hora de enjuiciar su obra ${ }^{1}$. Sin embargo, su calidad literaria empieza a ser valorada recientemente: fruto de este interés, se ha empezado a recuperar su poesía y su teatro en cuidadas ediciones ${ }^{2}$ que han devuelto su figura a la actualidad, después de casi doscientos cincuenta años olvidada ${ }^{3}$.

Entre sus habilidades poéticas se suele subrayar su innata habilidad para jugar con el valor polisémico del lenguaje y su facilidad para la irreverencia, sorteando la ofensa o el insulto. Buena muestra de estas cualidades resulta ser uno de los ejercicios por los que más justa fama recibió: las jácaras. Muy populares en su época, Cáncer se convirtió en un auténtico especialista, llegando a escribir al menos doce: siete serían propiamente rufianescas, y las otras cinco se catalogarían como divinas. A pesar de que en la época en que se escribieron (entre los años treinta y cuarenta) ya triunfaban sus hermanas dramáticas, ninguna de ellas debería considerarse como subgénero teatral; más bien todas ellas parecen deudoras de la popularización del género a partir del Escarramán de Quevedo (alrededor de 1611), quien fijó el modelo que triunfaría en los años siguientes. Es posible, como apunta F. Pedraza, que con Quevedo se llegara a la cima del género y que ninguno de sus seguidores o imitadores alcanzara la altura estética de los modelos quevedianos ${ }^{4}$, pero algunas propuestas, como las de nuestro escritor, tampoco desmerecen tan brillantes aportaciones. De su maestro, Cáncer heredó sobre todo los juegos de ingenio y de agudeza verbal que le proporcionaba el conceptismo y algunas imágenes, como veremos más adelante. Y es que influencias tan determinantes se colaron por las rendijas de gran parte de su poesía, sin que ello supusiera renunciar a un estilo personal.

Con las jácaras se manifestó un interés por reflejar el mundo o submundo del lupanar y el hampa, uno de cuyos tipos sociales, el jaque o rufián, ejercía de protagonista a partir de la descripción de sus hazañas. El estuche métrico

${ }^{1}$ PEDRAZA, Felipe; RODRÍGUEZ, Milagros. «Tiene composiciones líricas de escaso mérito» (Manual de literatura española. IV. Barroco: teatro. Navarra: Cénlit, 1980, p. 530). Marcelino Menéndez Pelayo le llama «poeta mediocre» (Obras de Lope de Vega, IX. Comedias de vidas de santos, I. Madrid: Atlas, 1964, p. CLXV. BAE-177.

${ }^{2}$ CÁNCEL Y VELASCO, Jerónimo. Obras varias. Solera, Rus (ed.). Larumbe, 2005. Clásicos Aragoneses, 38; la poesía completa en mi edición para la FUE, 2007. Su famoso vejamen, con mi propuesta para Criticón 96, 2006, pp. 87-114; y sus comedias en solitario por el SET. Cuadernos para la investigación de la Literatura Hispánica: Las mocedades del Cid. 1988, n. ${ }^{\circ} 23$; también publicada por A. Rodríguez, para las Comedias burlescas del Siglo de Oro. Iberoamericana-Vervuert, 2003, tomo IV, y La muerte de Valdovinos (n. ${ }^{\circ} 25$, 2000), amén de ediciones sueltas de su teatro breve en colecciones varias.

${ }^{3}$ Última edición de sus Obras varias, 1761; miscelánea que contenía gran parte de su obra poética, el vejamen literario y la comedia burlesca La muerte de Valdovinos.

${ }^{4}$ «De Quevedo a Cervantes: la génesis de la jácara». Actas del VII Congreso de la Asociación Internacional del Siglo de Oro (AISO). Close, Anthony (ed.). Madrid: Iberoamericana-Vervuert, 2006, p. 83. 
favorito para cantar esas aventuras era el romance, siguiendo la tradición del romance de germanía del siglo anterior; la lengua que se empleaba era la de la ladronería, la jerga de los delincuentes y maleantes, o sea, la germanía, «lenguaje paralelo y coexistente con la lengua normal» ${ }^{5}$. Pero esta definición genérica, identificada con la truhanesca, llevaba implícita también un paso más allá en la transgresión de la norma. Así, manteniendo estos paradigmas tan definidos, se llegó al atrevimiento, a la presentación de las vidas ejemplares vueltas a lo rufianesco. La técnica no era desconocida, pues intentos de divinización sobre la vida marginal se dan desde la misma génesis del género, como así lo atestiguan algunos romances escarramanescos de Lope de Vega, por los mismos años en que Quevedo escribía su obra fundacional ${ }^{6}$, insertos en la moda contrafactista de tan larga tradición. Resulta innegable que esa influencia, más la del conceptismo sacro, pudieron planear sobre el origen de la propuesta de Cáncer; pero su recorrido sería inverso. La asimilación, pues, de esta técnica al tema sacro dio como resultado lo que se ha venido en denominar «jácaras a lo divino», donde los personajes centrales son los santos de la Iglesia católica, quienes asumen así la apariencia de los jaques o maleantes.

La unión del espíritu religioso y el delincuente que el escritor supo captar, creo que se debe sobre todo a la propia decadencia del género, con la consiguiente exploración de nuevos caminos, pero también a la derivación grotesca del espectáculo teatral. Nace también el subgénero con cierta voluntad transgresora e irreverente hasta cierto punto, porque en manos de don Jerónimo aquello que adquiere mayor relevancia es su ingenio, su habilidad en conseguir en un auténtico tour de force transmutar categorías. La irreverencia, no obstante, llevaba consigo aparejada la ironía, no siempre captada por algún guardián de la fe, al que seguro debía de escocer. No obstante, cuando se publicó su poesía ${ }^{7}$ pasó todos los filtros de la censura curiosamente. No fue sino años más tarde, a causa sin duda del escándalo que debió causar el tratamiento burlesco del tema religioso para la nueva monarquía, cuando fragmentos o composiciones completas fueron expurgadas, como así consta en los índices de Valladares (1707) y Pérez Prado (1747). No es el caso del manuscrito que ahora se edita, puesto que nunca fue publicado, pero sí de otras compañeras de viaje sobre el mismo santo de Asís.

La habilidad de Cáncer consistiría, pues, en conseguir una muy particular laudatio de uno de los personajes más querido del santoral católico, lejos de maltratar su imagen fruto de una bufonada, como podría parecer a primera

${ }^{5}$ ALONSO HERNÁNDEZ, José Luis. El lenguaje de los maleantes de los siglos XVI y XVII: la germanía. Salamanca: Universidad de Salamanca, 1979, p. 11.

${ }^{6}$ Romance del Escarramán a lo divino (¿1612?) y Romance de Escarramán, vuelto a lo divino (1613), que recoge Elena di Pinto en La tradición escarramanesca en el teatro del Siglo de Oro. Madrid: Iberoamericana-Vervuert, 2005, pp. 414 y 449, respectivamente.

7 Obras varias. Madrid: Diego Díaz de la Carrera, 1651. 
vista. Además, san Francisco quizás fuera uno de los santos que mejor se podían prestar a un retrato marginal, sobre todo por dos circunstancias decisivas: la vida disipada antes de su conversión y su voluntad en marginarse. Recordemos que el joven de Asís renunció a toda su riqueza para ponerse del lado de los menesterosos o desheredados, marginales si se quiere, frecuentando incluso compañías que hoy consideraríamos poco recomendables. Esta dislocación de la realidad más el escarmiento público del delincuente, encuentra en la jácara su vehículo adecuado incluso para el mensaje religioso ¿O acaso no acogía Dios en su seno a los descarriados?

No se tiene constancia de las fechas en que pudieron escribirse estas obrillas al carecer de referencias internas y otros datos auxiliares, aunque si tenemos presente la fecha de publicación de su miscelánea Obras varias (1651), donde se recopilaba la mayor parte de su poesía; el hecho de que el grueso de la producción de Cáncer se escribió entre los años treinta y cuarenta del Seiscientos; y que las jácaras alcanzaron gran popularidad en los años cuarenta, por su expansión teatral y musical, es posible que fuera en esa década cuando se pergeñara la jácara que ahora presentamos. Sobre su autoría no parece existir duda. Sólo se conoce un texto manuscrito, sin título y con el nombre de Cáncer al frente, que encontramos en un códice de la Hispanic Society de Nueva York: [Cancionero] Varias flores ${ }^{8}$, tomo II, folio 101 recto y vuelto, flanqueado por dos quintillas de ciego dedicadas también al santo de Asís del mismo escritor. A pesar de que no ha visto nunca la luz, se puede considerar hermana temática y estilísticamente de otra jácara a san Francisco de la que copia incluso la última cuarteta que se publicó en las Obras varias $^{9}$. El estilo y los recursos son inconfundibles del autor. No se sabe los motivos por los que éste no seleccionó su texto para la edición que preparó de su obra poética, aunque posiblemente al incluir otros trabajos del mismo estilo y protagonista, decidiera descartarlo.

Es probable pensar, por otra parte, que tratamiento tan jocoso sería del agrado del público, igual que ya lo era en la tradición medieval, como nos recuerda E.R. Curtius a propósito de la comicidad hagiográfica: «Los elementos humorísticos forman, pues, parte del estilo de las vidas de santos en la Edad Media; estaban implícitos en la materia misma, y podemos estar seguros de que el público los esperaba» ${ }^{10}$. La jácara cómico-hagiográfica barroca, por tanto, no es producto de ninguna creación de la época, sino que se inserta dentro de una corriente medieval eclesiástica europea de bufonada que alcanzó otros géneros como sucedió también con la epopeya. Lo que sucedió es que encontró en la cultura barroca, en la estética del feísmo, en los inten-

\footnotetext{
8 Ver nota 29.

${ }^{9}$ A san Francisco. folio 66r, con errata en foliación, corresponde a 70r; y pp. 276-278 de mi edición sobre la poesía completa de Cáncer ya citada.

${ }^{10}$ Literatura europea y Edad Media latina. México: Fondo de Cultura Económica, 1976, p. 609 .
} 
tos de sorprender o impresionar al público o en la crisis social, el cauce ideal para intensificar y dar carta de naturaleza a sus procedimientos. Por otro lado, también contribuyó el hecho de que durante el primer tercio del siglo XVII su cauce formal, los romances de germanía, ya constituían un notable éxito de público. Tanto es así que, debido a su popularidad, las vidas de los jaques pasaron a los escenarios, donde se esperaban con verdadero interés e impaciencia: «jjácara, jácara!», gritaban los mosqueteros al finalizar el espectáculo, por lo que obligaba a las compañías de representantes a incluir en su repertorio algunas de estas piezas ${ }^{11}$. El interés del público sobre las clases marginales, sus ruindades, lenguaje o pillerías, era foco de diversión y entretenimiento, pero también motivo literario para los escritores, quienes volcaban su mirada sobre un país que veían y reflejaban en descomposición.

Las jácaras a lo divino de Cáncer se definen a partir de la conjunción de unas modas, recursos o fórmulas que influyeron decisivamente en la constitución de su obra y contribuyeron a fijar su estilo: los contrafacta, el conceptismo y la germanía, la proyección teatral, los pliegos de cordel y la técnica «vida y milagros». Por un lado, el barroquismo y sus derivaciones; por otro, la «función juglaresca del lenguaje». Si leemos los primeros versos de sus otras compañeras a lo divino («Atienda todo viviente / y la historia contaré»; «Atención, que ahora quiero / contar la vida y milagros»; «Un ciego soy que he venido / a cantar en esta tropa»...), damos con la importancia del poeta-narrador-ciego y con el valor fundamental de lo narrativo en este tipo de piezas; son líneas en las que destacó nuestro poeta y que, por otra parte, enlazaba con toda la tradición del romancero que, a pesar de ser un género básicamente leído en el siglo XVII, guardaba todavía todos los resortes de la oralidad que le caracterizaron durante siglos. El «Cante mi germana lira» del íncipit de la jácara nos remite a esa tradición, aunque también nos recuerde sus orígenes musicales.

Si tomamos como referencia las definiciones de Autoridades sobre la jácara, vemos que éstas se bifurcan según si damos preponderancia a su condición poética («Composición poética que se forma en el que llaman romance, y regularmente se refiere en ella algún suceso particular o extraño. Úsase mucho el cantarla entre los que llaman jaques, de donde pudo tomar el nombre») o musical ( «Se toma también por el tañido que se toca para cantar o bailar»; «Se llama asimismo un especie de danza formada al tañido y son proprio de la jácara»). Aunque no se descarta su dimensión musical (es posible que se cantara al 'tono de'), no debe confundirnos el empleo en el íncipit del término «lira», instrumento nada plebeyo, nunca empleado para acompañar este tipo de composiciones. Más bien se observa, en esta alusión, un recurso típico de la oralidad, común en aquel tiempo donde se recitaban y can-

${ }^{11}$ DELEITO Y PIÑUELA, José. ...También se divierte el pueblo. Madrid: Alianza Editorial, 1988, pp. 201-202. 
taban poesías de todo tipo ${ }^{12}$; y también un viejo tópico de raigambre literaria como fórmula de comienzo: la invocación a la lira, identificada con el arte de componer poesía. No obstante, Cotarelo y Mori, al tratar de las jácaras a lo divino, insiste en su dimensión músico-teatral: «El hecho de componer Cáncer y algunos otros jácaras de esta clase prueba que debieron de cantarse en los teatros ${ }^{13}$, o en la calle, al modo de los pliegos de cordel, añadiría. En cualquier caso, este rasgo escénico no debe confundirse con la jácara entremesada, género al que no pertenece. Remite más bien a esa indefinición entre lo poético y lo musical, con rasgos de la literatura de cordel, que ya sugería Cervantes en su comedia El rufián dichoso (publicada en 1615):

\footnotetext{
Toquen, que esta es la casa, y al seguro, que presto llegue el bramo a los oídos de la ninfa, que he dicho, jerezana, cuya vida y milagros en mi lengua viene cifrada en verso correntio. A la jácara toquen, pues comienzo ${ }^{14}$.
}

Delimitado el espacio, pues, el texto recoge el itinerario básico del género rufianesco, a saber: vida, miserias y castigo de un delincuente mayor.

\section{RETRATO DE FranCisCo DE Asís}

Tanto si es ejecución oral como lectura silenciosa, la jácara profana una de las figuras más queridas del panteón sagrado de la Iglesia católica: Francisco de Asís, convertido ahora en un vulgar pendenciero y jugador, probablemente del Madrid barroco ${ }^{15}$. Al igual que en la jácara impresa ${ }^{16}$, de la que ésta puede considerarse legítimamente una continuación o un antecedente, el retrato se sostiene sobre cuatro principios básicos:

1. La asimilación de los preceptos truhanescos por parte de la figura religiosa central.

2. La formulación narrativa.

12 FRENK, Margit. «La literatura oral». Historia y crítica de la literatura española. 3/ 1. Siglos de Oro: Barroco. Primer suplemento. EGIDO, Aurora (ed.). Barcelona: Crítica, 1992, p. 52.

13 Colección de entremeses, loas, bailes, jácaras y mojigangas. Madrid: Bailly/Baillière, 1911, vol. I, p. CCLXXXII. NBAE, 17.

${ }_{14}$ En Ocho comedias, y ocho entremeses nuevos, nunca representados. Madrid: Viuda de Alonso Martín, 1615, jornada primera, fol. 91r.

15 No hay localización ni en ésta ni en las otras jácaras de Cáncer, aunque si tenemos a la vista el resto de su poesía y que la capital del reino era lugar de afluencia de la gente más variopinta y foco de concentración de truhanes y delincuentes, probablemente sugiera esa ciudad en su descripción.

16 Véase nota 9. 
3. El empleo de la germanía.

4. El valor disémico del lenguaje.

De esta estructura básica de la pieza, se debe destacar, por lo original, lo que caracteriza al protagonista: andanzas y caída en desgracia de un maleante atípico. Al introducirse, aquí, una variante significativa, confluyen en la obra dos planos que se van superponiendo según el interés del poeta: el devoto y el marginal. Por el primero llegamos a la auténtica historia y leyenda del santo italiano, al referente biográfico; por el segundo, a la transformación de una vida edificante en otra más dudosa o de un argumento ejemplar en otro deshonesto. Hay preponderancia lógica del plano marginal sobre el fervoroso, aunque ambos van unidos, siendo el primero el que proporciona, a través del equívoco, algunas situaciones para ilustrar el segundo.

Referente biográfico:

- Familia y adolescencia: oficio familiar, autoridad paterna y expulsión de su tierra natal.

- Hagiografía: tentaciones, sayal, mortificaciones, votos religiosos, fundación de la tercera orden, milagros y la regla franciscana.

Referente rufianesco:

- Categoría: jayán, mercader (ladrón).

- Habilidades: destreza con la espada, jugador de cartas.

- Comportamiento: derrochador, pendenciero, rebelde, bebedor, cobarde ante el tormento, cohecho.

- Amistades: mundo de la heria (hampa), malas compañías, pobretes.

- Vestimenta: andrajoso.

Algunos términos son clave y se repiten tanto en la jácara impresa como en la manuscrita: jayán, pendencia, diestra/destreza, hembra y cuerda. Por ellos llegamos a campos semánticos muy significativos: la tipología de delincuente, la violencia, la habilidad con la espada, el elemento femenino y la justicia o potro de tormento, respectivamente. La pendencia y la violencia van estrechamente ligadas a su formación como 'jayán', condición que ejerce no como mantenedor de mancebías (jácara impresa) sino como diestro espadachín. El jayán, «rufián a quien respetan» ${ }^{17}$, pertenece, según la jerarquización de la valentónica establecida por Alonso Hernández ${ }^{18}$, al último escalón de la carrera del maleante, el de los delincuentes de más categoría dentro de las clases marginales, pero también, no lo olvidemos, a la degradación del héroe, característica muy barroca. Su superioridad la demuestra aquí con el uso de

17 HIDALGO, Juan. Vocabulario de germanía. En Poesías germanescas. HILL, John M. Bloomington: Indiana University Publications, 1945, pp. 104-124. Humanities Series, 15.

${ }^{18}$ Cfr. Alonso Hernández, 1979, pp. 95-107. 
la espada y de la fuerza física, poco queda ya de aquel Francisco predicando a las aves o de endeble apariencia que nos ha legado la iconografía medieval y cristiana. A lo que debemos añadir su oficio como 'mercader' («ladrón que anda siempre donde hay trato», en germanía), que remite a las malas compañías, motivo de su ruina y posterior apresamiento. Éste es uno de los hallazgos de la jácara, el ambiente de tabernas y garitos del inframundo social donde Francisco demuestra su pasión por la bebida y el juego, sus relaciones con el hampa y sus inclinaciones agresivas contra otros marginados, cumpliendo así con tres de las cualidades de todo buen jayán que se precie: buen bebedor, buen jugador y gran peleador. Esta tendencia al exceso forma parte de su respuesta devoradora ante el mundo, ante un sistema de valores morales al que contrapone otras motivaciones más materialistas o ruines. La jácara describe también las circunstancias de su apresamiento en la mesa de juego de un garito, y dos notas muy características de este tipo de composiciones: la lucha entre jaques y la aparición del padre, aquí como nota discordante. Carece, no obstante, de la crueldad que define a este tipo de personajes.

Resulta inevitable observar en la jácara, la indeleble huella que debió de causar en el autor la lectura de modelos anteriores. La correlación 'tabernabebida-apresamiento-condena', más alguna imagen como la de ahogar las pendencias en vino, se describe asimismo en las dos jácaras fundacionales de Quevedo: la carta de Escarramán y la respuesta de su prostituta, la Méndez ${ }^{19}$. El final penal de los delincuentes es también similar en ambos casos, con la salvedad de que mientras Escarramán es condenado a galeras y termina con sus huesos en la cárcel, nuestro Francisco se libra de la pena capital gracias al soborno de la justicia. La crítica a la venalidad del sistema judicial era recurrente en este tipo de composiciones. Por otro lado, ante los métodos de indagación de la verdad por parte de la ley, se dejaba al descubierto la «arrogancia» del delincuente, suerte de estoicismo muy común ante el castigo fatal, que ayudaba a definir su estética moral. Era la respuesta individual ante la presión social sobre aquellos que transgredían la norma. Sin embargo, en nuestro caso se observa una diferencia fundamental que desenmascara al personaje: la cobardía ante el tormento de la cuerda no parece corresponder a su categoría. Se sobrentiende, pues, que con su rápida confesión en el potro de tortura rompe una de las leyes más sagradas del código del hampa: la delación («Cantó Francisco de plano / sus culpas a media vuelta»); pero también se rompe con ese aire de fatalismo tan típico del género, y con el cinismo o la jactancia de los jaques, «especie de vanidad delincuente que consiste en morir gallardamente» ${ }^{20}$, como parte del espectáculo o teatralización en

${ }^{19}$ Poesía original completa. Blecua, J.M. (ed.). Barcelona: Planeta, 1981, n. ${ }^{\text {os }} 849$ y 850. (Clásicos Universales Planeta, 22).

${ }^{20}$ Evangelina Rodríguez y Antonio Tordera. «Ligaduras y retórica de la libertad: la jácara». El teatro menor en España a partir del siglo XVI. Madrid: Anejos de la revista Segismundo, 5 (CSIC), 1983, p. 127. 
que se convertían los castigos públicos ${ }^{21}$. Todo parece apuntar, pues, hacia la parodia.

\section{LENGUAJE Y TRADICIÓN}

Una de las constantes en la poética de Jerónimo de Cáncer es la tendencia hacia una dialéctica entre lo serio y lo burlesco. Este tratamiento, que recorre como una espina dorsal toda su trayectoria lírico-dramática, tiene aquí su traducción en el dispositivo lingüístico y en el enfrentamiento entre opósitos: el humor y la religión, lo deshonesto y lo sagrado. Resulta difícil desligar en esta huella su natural espíritu jocoso. Fenómeno extraliterario donde se quiera, pero que en Cáncer resulta un marco de referencia obligado, que se manifiesta en su dominio lingüístico y en sus abundantes juegos verbales. La jácara que ahora presentamos supone, pues, un excelente muestrario de su ingenio, de su habilidad en combinar intencionalidad recreativa y laudatio, broma y materia seria, risa y elaboración poética. Este rasgo estilístico, frecuente tanto en sus comedias burlescas, como en sus entremeses o en su poesía, se refleja aquí en el extraordinario arsenal de juegos de ingenio que le proporciona el conceptismo, en especial el juego disémico, y el idiolecto de los delincuentes. Por otro lado, el asunto también se prestaba a ello. El retrato de un héroe/santo desacreditado corría en paralelo a la degradación del romancero tradicional que había derivado en este tipo de espectáculos grotescos, como posible metáfora también del declive del imperio.

Bajo la fórmula narrativa donde prima la acción sobre la descripción, se continúa con la tradición romanceril heredada de los pliegos sueltos donde se tomaron varios procedimientos: la narración de las vidas edificantes; la «moraleja» final a modo de aviso para navegantes; el íncipit de la jácara, que nos recuerda la pagana invocación a las musas; el popularismo en la expresión; el humorismo; o la misma incidencia en la verosimilitud de lo relatado de la primera cuarteta. Esta relación con la estructura de los pliegos de cordel es la que nos conduce a la influencia de los procesos de oralidad, al modo de los 'hechos para contar', presente en toda la serie de «profanizaciones» de su poesía.

Sobre el humorismo del lenguaje literario, un conocido campo de experimentación linguística se abre ante el autor: su inclinación hacia el juego disémico, los desplazamientos o las asociaciones, con especial dedicación al disparate. Cáncer ofrece en sus versos una buena muestra de su habilidad más representativa. Resulta difícil leer su poesía sin adivinar detrás de cada término o expresión una segunda o tercera lectura que invita a la jocosidad. La introducción de los dobles sentidos en las jácaras a lo divino en general, no

${ }^{21}$ Sobre la tortura se puede consultar Tomás y Valiente, F. La tortura en España. Estudios históricos. Barcelona: Ariel, 1973. Ariel Quincenal, 77. 
sólo funciona como mecanismo lúdico en sí, sino también como dispositivo indisociable al género, barrera de alusiones maliciosas que el público captaba rápidamente por lo disparatado o risible de la propuesta. La jocosidad, pues, es consustancial a su propia naturaleza. Estos juegos de agudeza verbal son, por lo demás, moneda corriente en el conceptismo, y funcionan en esta poesía en la mayoría de los casos como referente al plano biográfico o devoto. Así, cuando en los primeros versos se presenta al santo como «mercader que andaba con lindas piezas», resulta obvia la remisión biográfica; pero también la ladronesca («ladrón que anda siempre donde hay trato»). Si andaba «roto en el mundo» no es porque sólo vestía andrajosamente sino sobre todo porque llevaba una vida licenciosa. Son estos casos en que la doble lectura es pertinente; pero en otros, una de las dos soluciones es absurda, predominando el plano marginal, incluso con lecturas múltiples. Cuando el padre de Francisco lo encuentra en las ermitas ahogando las pendencias, es evidente que se alude a la germanía, donde «ermitas» debe tomarse por 'tabernas' y «ahogando las pendencias», por 'bebiendo' y por 'apretando el cuello' a otros rufianes («pendencias»).

En la siguiente cuarteta el referente primero es el religioso, tomado de la tradición apócrifa del santo, posiblemente de la Leyenda mayor de san Buenaventura, quizás una de sus primeras fuentes históricas; pero inmediatamente, en la segunda parte de la estrofa, el narrador introduce el chiste al entrar en colisión con el léxico del juego:

\footnotetext{
Resucitaba los muertos no más de porque él quisiera, y desta suerte dejó algunas muertes mal hechas. (vv. 21-24)
}

'Hacer una muerte' es en germanía ganar a alguien a las cartas, por tanto, si «dejó / algunas muertes mal hechas», parece expresar mala suerte en el juego. Es un tipo de ingeniosidad, llamémosla fácil, que sin duda estaba al servicio de divertir. En otras ocasiones, los dos planos no entran en colisión y se da un solo referente con dos o más lecturas que a menudo puede funcionar como ampliación sinonímica: «pobretes», 'infelices' o 'maleantes de poca categoría'; «brazos», ‘fuerza' o 'favorecedores'...; o antonímica: «hembra», 'mujer' o 'prostituta'. El contexto es el que suele reclamar la lectura predominante sin menoscabar la otra: «media vuelta» es 'brevemente', pero sobre todo «la vuelta que da el verdugo a las clavijas apretando las cuerdas al cuerpo del reo» ${ }^{22}$.

Otra marca de estilo de don Jerónimo es el uso de las frases hechas o refranes, como parte de su gusto por lo popular. Aparecen también con doble

${ }^{22}$ ALONSO HERNÁNDEZ, José Luis. Léxico del marginalismo del Siglo de Oro. Salamanca: Universidad de Salamanca, 1976. 
recorrido, según si se toman directamente, si se manipulan o si se cargan con lecturas múltiples. De la primera posibilidad, «salir a campaña», de léxico militar; de la segunda, «dejó / algunas muertes mal hechas», ya comentada, o «dio ocasión», de 'poner en ocasión'; de la tercera, «ahogando pendencias», «a media vuelta»y «cantó de plano», también citadas, todas ellas germanescas, según se lea.

Finalmente, el idiolecto que adoptaron los delincuentes y las prostitutas durante los siglos XVI y XVII: la germanía, «código que garantiza el tráfico y la supervivencia ${ }^{23}$ de estos personajes. Esta suerte de lenguaje de los bajos fondos ya había llegado a mitad de siglo lexicalizado al convertirse en lengua literaria sobre todo a partir de la contribución de Quevedo al género. La jácara es a la narración lo que la germanía al lenguaje. Y a través de éste penetramos en su valor sociológico, la preocupación por los juegos de la agudeza y el ingenio junto a los elementos evocadores y caracterizadores de la condición social del protagonista. Aunque el valor como documento sociológico no sea el primordial, es evidente que a través de él llegamos a toda la retórica de la germanía, a sus campos semánticos y casuística. Por esta puerta entramos en el lenguaje procedente de la violencia (ahogar pendencias, dar ocasión, venidas, tretas), de la justicia (cantar, cuerdas y vuelta) o del juego (ermita, mesa, hacer una muerte). Los calificativos distintivos del santo-rufián son indicadores del tipo de transgresiones sociales que lo distinguirán (jayán, mercader, diestro y roto), al tiempo que la descripción de las habilidades de sus compañeros del hampa completan su propio retrato (pobretes, pendencias, hembras y camaradas). He atestiguado un total de quince voces puramente germanescas y veintiuna si juntamos las asimiladas, la mayoría de ellas sustantivos (15) y, en menor medida, expresiones (4).

La predilección de Cáncer por el octosílabo tiene su reflejo en una forma que se adaptaba perfectamente a contar (o cantar) historias: el romance, la estructura métrica del género y la forma favorita de los poetas del Siglo de Oro para la narración. En este punto el autor sigue la tradición del siglo anterior con la división típica de las secuencias en cuartetas que encontramos a partir del romancero nuevo. Por lo general, estas unidades de composición, «la más corriente de las estrofas populares $»^{24}$, se adaptan perfectamente al contenido y suelen contener un solo pensamiento (salvo la cuarta y la quinta estrofa), concluido con una pausa final. Es posible que ello tuviera que ver con su estructura musical. Los romances no sólo eran obras literarias sino también musicales. Para Menéndez Pidal, el romance es una «poesía destinada a vivir en las notas del canto y no en los renglones del cartapacio» ${ }^{25}$ (recordemos el íncipit de la jácara).

\footnotetext{
${ }^{23}$ Cfr. RODRÍGUEZ, Evangelina; TORDERA, Antonio, 1983, p. 132.

${ }^{24}$ NAVARRO TOMÁS, Tomás. Métrica española. Barcelona: Labor, 1991, p. 547.

${ }^{25}$ Romancero hispánico (hispano-portugués, americano y sefardí). Teoría e historia. Madrid: Espasa-Calpe, 1953, II, p. 17, 2 vols.
} 
La fórmula que más repite el poeta en estas combinaciones es la pausa después del segundo verso (ocho de las doce cuartetas) seguida de la copulativa «y» en seis casos y del relativo «que» en los otros dos. En otras dos situaciones más, la pausa se encuentra en el primer verso, seguido también del mismo conector copulativo. Esta disposición binaria o efecto rítmico de los períodos gramaticales parece subrayar uno de los rasgos inherentes al romance, el de la oralidad (¿teatral?) ${ }^{26}$ o la narración: «el tipo estrófico binario, es el más antiguo y frecuentado en la estrofa castellana. Representa la fórmula rítmica más sencilla, y más cercana a la recitación coloquial; y ha sido el instrumento secular del popularismo poético castellano ${ }^{27}$. En cuanto a la estructura rítmica, el poeta opta por las modalidades heroicas ${ }^{28}$ (mixtas en la terminología de Navarro Tomás) debido a su carácter narrativo (quince frecuencias) y, sobre todo, a la combinación de sólo dos acentos rítmicos (en tercera o cuarta y séptima, melódicos y sáficos, respectivamente), que vemos en veintidós ocasiones. Por último, la rima vocálica es en 'e-a' en todos los versos pares.

\section{ESTA EDICIÓN}

Reproduzco íntegramente el manuscrito encontrado en la HSA ([Cancionero] Varias flores $^{29}$, tomo II, folio 101 recto y vuelto), procurando ser escrupuloso con el texto, manteniendo todas sus peculiaridades fonéticas (por ejemplo, el conglomerado 'desta'). He modernizado las grafías ('qualquiera' = cualquiera; 'bentaja' = ventaja...), acentuado ('ocasion' = ocasión) y puntuado siguiendo la normativa vigente; he añadido mayúsculas donde faltaban ('asis' = Asís) y la letra $h$ donde la norma hoy la coloca ('aber' = haber). También se han separado las palabras cuando la ocasión lo requería ('dela' = de la; 'anadie' = a nadie...) y desarrollado la abreviatura de Francisco ('Fran' ${ }^{\text {co' }}$ ). Por último, regularizo tipográficamente los versos separando las cuartetas que en el manuscrito aparecían juntas. En cuanto a las notas a pie de página, aparte de las definiciones de los diferentes repertorios léxicos consultados, he añadido algunos ejemplos paralelos ilustrativos de cada caso e interpretado algunos pasajes dificultosos o de múltiples lecturas, tan típicos del estilo del autor, que espero ayuden a la mejor comprensión de la palabra, expresión o verso anotados.

${ }^{26}$ Cfr. NAVARRO TOMÁs, Tomás, 1991, p. 289.

27 BALBÍN, Rafael de. Sistema de rítmica castellana. $3^{\mathrm{a}}$ ed. Madrid: Gredos, 1975, p. 274 .

${ }^{28}$ Sigo la terminología de Varela, Elena; Moíño, Pablo y Jauralde Pou, Pablo. Del $M a$ nual de métrica española. Madrid: Castalia, 2005, p. 111. Castalia Universidad, 3.

${ }^{29}$ Hispanic Society of America, B2484, con letra del siglo XVII aunque de distintas épocas. La jácara se edita con el permiso concedido por la Institución. 
Finalmente, añado a continuación de la jácara inédita las dos quintillas de ciego sobre el mismo asunto que aparecieron junto a ésta en el manuscrito de la Hispanic Society. Ya se habían publicado con anterioridad en la edición princeps de su poesía (1651) y en las ediciones de Rus Solera (2005) y de Juan Carlos González (2007) $)^{30}$.

\section{[A san Francisco de Asís]}

\section{JÁCARA. CÁNCER}

Cante mi germana lira el valor y la destreza de aquel jayán que en Asís un tiempo fue de la heria.

Destruyéronle pobretes con quien gastaba su hacienda, que como era mercader andaba con lindas piezas.

${ }^{30}$ Sigo para su edición mi trabajo para la FUE (2007). Cfr. nota 2.

1 germana: 'rufiana: relativa a la germanía, la vida de valientes y rufianes' (germanía) (Léxico del marginalismo, a partir de ahora 'Léxico'), la 'hermandad' del hampa; pero también 'lenguaje germanesco'.

2 destreza: «Se llama por antonomasia el arte del juego de armas u de esgrima» (Diccionario de Autoridades, 'Autoridades'). Cervantes, Don Quijote: «Mirad, bachiller —respondió el licenciado-, vos estáis en la más errada opinión del mundo acerca de la destreza de la espada, teniéndola por vana» (ed. F. Rico, II, p. 787). Quevedo, La vida del Buscón: «Yo soy examinado y traigo la carta, y, por el sol que calienta los panes, que haga pedazos a quien tratare mal a tanto buen hijo como profesa la destreza» (ed. Cabo Aseguinolaza, p. 111). El mismo escritor dedica a este arte de la destreza o esgrima el baile Las valentonas, y destreza (Poesía original completa, ed. J.M. Blecua, n. ${ }^{\circ} 866$ ).

3 jayán: «Germ. Rufián respetado por todos» (Léxico). Era el grado máximo al que podían aspirar los maleantes. Su aspecto solía ser amenazador debido a su imponente físico. Quevedo, La vida del Buscón: «Había en el calabozo un mozo tuerto, alto, abigotado, mohíno de cara, cargado de espaldas y de azotes en ellas. Traía más hierro que Vizcaya: dos pares de grillos y una cadena de portada. Llamábanle el Jayán» (ed. cit., p. 173).

4 heria: «Germ. Hampa» (Léxico). La vida y hechos de Estebanillo González: «y como siempre he sido inclinado a toda gente de heria y pendón verde, al punto vi esta cuadrilla de bravos hice camarada con ellos» (ed. Carreira-Cid, I, p. 179).

5 destruyéronle: lo mismo que 'arruináronle': «Se toma también por gastar y malbaratar la hacienda» (Autoridades).

pobretes: «el sujeto inútil y de corta habilidad, ánimo o espíritu; pero de buen natural» (Autoridades); pero en germanía, «un tipo de maleante de poca categoría que en la cárcel sirve en algún oficio a los otros detenidos de más categoría, por ejemplo, para servirles de enlace o recadero» (Léxico). Calderón, El alcalde de Zalamea: «REBOLLEDO. Chispa, ¿qué es esto? / CHISPA. Ahí un pobrete, que queda / con un rasguño en el rostro. / REBOLLEDO. Pues, ¿por qué fue la pendencia?» (ed. Escudero Baztán, vv. 1051-1054).

7 mercader: alusión al oficio familiar, al ser el padre un rico mercader de telas; pero en su lectura germanesca mercader es «ladrón que anda siempre donde hay trato» (Léxico).

8 lindas piezas: no se refiere el poeta sólo a las telas, sino a las piezas de plata, a su riqueza; y, por alusión a los 'pobretes', al «muy astuto, bellaco y de malas propiedades» (Autoridades). El juego con los significados es una característica de toda la poesía de Cáncer. Quevedo emplea la misma expresión en Sueño del Infierno: «Había pipotes de médicos y muchísimos coronistas, lindas piezas, aduladores de molde y con licencia...» (ed. Arellano, p. 267). Rojas, La Celestina: «Mala landre te mate si de risa puedo estar, viendo el desamor que debes de tener a esa vieja que su nombre has vergüenza nombrar. Ya me voy recordando della. Una buena pieza; no me digas más» (ed. Lobera-Serés-Díaz Mas-Mota-Arzálluz-Rico, p. 116). 
Corregíale su padre, y a cualquier hora que fuera, le encontraba en las ermitas ahogando las pendencias.

Salió a campaña el jayán con el hombre de más fuerza, y a las primeras venidas, se hirieron con una treta; pelearon igualmente
sin ventaja ni cautela,
y desde aquestas heridas
no hubo en los dos diferencia.

9 corregíale: «advertir, amonestar para la enmienda, reprehender y castigar» (Autoridades, s.v. corregir). padre: don Pedro Bernardone, rico comerciante en paños. Las relaciones entre padre e hijo fueron tensas desde que éste renunció a la extraordinaria herencia paterna para vivir como un pobre.

11 ermitas: «Germ. Bodegón o taberna» (Léxico). Quevedo, baile Los borrachos: «Envainan, y en una ermita beben, ya amigos con sorna, / su pendencia hecha mosquitos» (Poesía original completa, ed. cit., 873, vv. 33-35). Estebanillo: «lo convidé a beber dos frascos de vino en una ermita del trago» (ed. cit., I, p. 147).

12 ahogando las pendencias: «frase burlesca con que se da a entender que alguna pendencia se compuso y acabó en la taberna bebiendo vino» (Autoridades). Así lo vemos en la Carta de Escarramán a la Méndez (v. 12) y en su continuación, Respuesta de la Méndez a Escarramán (v. 19) donde Quevedo hace ahogar las penas de su protagonista en vino (Poesía original completa, ed. cit., 849 y 850). En la lectura germanesca pendencias son 'rufianes'; por tanto, ahogando es 'quitando la vida a otro apretándole el cuello'.

13 Salió a campaña: «ir a la guerra» (DRAE, s.v. salir a campaña, o a la campaña); es decir, 'salió a combatir'. Es terminología militar; pero también podría ser deformación de «saltar en campaña. Echarse al monte; hacerse bandido de caminos» (Léxico). En estos versos se recoge uno de los distintivos de toda jácara: la lucha entre jaques.

14 de más fuerza: debe entenderse aquí como 'violento'. Auto sacramental de Escarramán: «he cometido / fuerzas, latrocinios, muertes, / y con todo me he salido» (vv. 83-85, en La tradición Escarramanesca en el teatro del Siglo de Oro, ed. E. di Pinto, p. 177). Quevedo, soneto No se disculpa, como los necios amantes: «Fuerza, no atrevimiento, fue el quereros, / y presunción penar tan altamente» (Poesía original completa, ed. cit., 301, vv. 3-4).

15 venidas: «Lance de espada» (Léxico, s.v. venida).

16 treta: «Term. de esgrima. El concepto o pensamiento que forma cualquiera de los batalladores para la defensa propria y ofensa de su contrario, y acción correspondiente a él, sin que éste pueda fácilmente comprehenderle en cualquiera de los lances y tiempos que se ofrecen, como son estocada, tajo, medio tajo, revés y medio revés y otros» (Autoridades). A. Hernández precisa: «Engaño que traza y ejecuta el diestro, para herir o desarmar a su contrario o para defenderse» (Léxico). Quevedo, Buscón: «Eso -me dijo- era que se me ofreció una treta por el cuarto círculo con el compás mayor, continuando la espada para matar sin confesión al contrario» (ed. cit., p. 109). Lope de Vega, El caballero de Olmedo: «Las manos haciendo tretas, / que, como juego de esgrima, / tiene tanta gracia en ellas, / que señala las heridas» (ed. F. Rico, vv. 87-90).

18 ventaja ni cautela: ambos términos señalan algún tipo de artimaña; ventaja es «fullería o trampa que se ejercita en el juego y puede ser de cualquier tipo» y cautela, «engaño, trampa; las primeras trampas que un fullero utiliza en el juego antes de la verdadera fullería a la que sirven de preparación» (Léxico). Tirso, El burlador de Sevilla: «dice que fue el Duque Octavio / quien, con engaño y cautela, / la gozó» (ed. López-Vázquez, vv. 149-151). Rojas, La Celestina: «Señora mía, no quiera Dios que yo te haga cautela» (ed. cit., p. 303). Calderón, El alcalde de Zalamea: «primero introdujo en casa / tan nunca esperada cisma / de traiciones y cautelas, / de pendencias y rencillas» (ed. cit., vv. 1912-1915).

19 heridas: aparte de su sentido recto, por alusión a las 'tretas' mencionadas antes, «asunto o negocio que no está claro» (Léxico). 
Resucitaba los muertos

no más de porque él quisiera,

y desta suerte dejó

algunas muertes mal hechas.

No se sujetaba a nadie,

y al echalle de la tierra

no obedeció hasta que tuvo

orden segunda y tercera.

Un día para perderse

le dio ocasión una hembra,

y así quedó sobre ascuas

de haber tenido paciencia.

$\mathrm{Y}$ andando roto en el mundo

entre sacos y asperezas

21 Resucitaba los muertos: alusión a supuestos milagros de Dios por intercesión de san Francisco una vez muerto éste, como el de la mujer resucitada de Monte Marano (Italia). Forma parte de la leyenda que los mismos franciscanos fabricaron por semejanza a la de Cristo. El episodio está tomado de la Leyenda Mayor 2,1 de san Buenaventura, contemporáneo del santo.

22 no más de: 'solamente'. Calderón, La dama duende: «Yo tengo de conocerla, / no más de por el cuidado / con que de mí se recela» (ed. F. Antonucci, vv. 130-132).

24 muertes mal hechas: aparte de su sentido recto, cómico, es alusión a la expresión 'hacer una muerte', «germ. Ganar a alguien jugando a los naipes» (Léxico). Claro, si «resucitaba los muertos» no 'hacía bien la muerte', por tanto, no ganaba a las cartas.

25 se sujetaba: 'se sometía'.

26 tierra: puede que sea alusión a la salida de Francisco de su ciudad natal después de renunciar a la herencia paterna y abrazar la pobreza, dejando amigos y familia; pero también podría ser fabulación del poeta para incidir en la contumacia del jayán-santo.

28 orden segunda y tercera: es alusión a las tres órdenes franciscanas: los Frailes Menores, o primera orden, fundada por san Francisco en 1209; las Hermanas Descalzas o Clarisas, segunda orden, fundada por santa Clara de Asís y san Francisco en 1212; y los Hermanos y Hermanas de Penitencia, tercera orden, ideada también por san Francisco y fundada en 1221. Pero también es la insistencia en que le conminaron a salir de la 'tierra', ya convertido en mendigo.

29 perderse: «Significa también conturbarse o arrebatarse sumamente por algún accidente, sobresalto u pasión, de modo que no se pueda dar razón de sí» (Autoridades). Calderón, La dama duende: «Es / un loco, un impertinente, / un tonto, un simple, / un menguado / que por tal dama se pierde» (ed. cit., vv. 2525-2528).

30 le dio ocasión: es variante de «poner en ocasión. Vale poner a alguno en riesgo o peligro u provocarle e incitarle» $(A u t)$. Calderón, La dama duende: «Miren la mala mujer / en qué ocasión te había puesto!» (ed. cit., vv. 515-516). Guillén de Castro, Las mocedades del Cid: «¿Saliste de la ocasión / sin peligro y sin heridas?» (ed. S. Arata, vv. 1365-1366). También es voz de germanía, «pendencia o cuestión de alboroto» (Léxico).

hembra: es 'prostituta' en germanía. No he encontrado el episodio en ninguno de los textos consultados. Podría tratarse de alguna invención del poeta o de alguna de las tentaciones apócrifas que circularon sobre su leyenda.

33 roto: tiene el sentido de 'andrajoso' ('ropas rotas'); aunque también, «se aplica al sujeto licencioso, libre y desbaratado en las costumbres y modo de vida, y también a las mismas costumbres y vida de semejante sujeto» (Autoridades). Quevedo, Buscón: «Desconociéronme en esto las huéspedas y respondieron que allí no vivía sino un don Ramiro de Guzmán, más roto que rico, pequeño de cuerpo, feo de cara y pobre» (ed. cit., p. 182).

34 sacos: la vestidura tosca y áspera de Francisco. Asperezas también es «el rigor de las obras penales, como la mortificación, ayunos, etc.» (Autoridades). Cervantes, Don Quijote: «Reducíansele a la memoria los maravillosos acaecimientos que en semejantes soledades y asperezas habían sucedido a caballeros andantes»(ed. cit., I, p. 251). 
[le] oyeron solos tres votos,

Prendiéronle con algunos camaradas de su mesa, y para que confesasen les apretaron las cuerdas.

Cantó Francisco de plano sus culpas a media vuelta, y tomó por buen partido que le diesen una jerga.

$\mathrm{Y}$ a no tener tantos brazos ya justiciado estuviera, que mil veces ha tenido el borriquito a la puerta.

$35[l e]$ : la lectura se hace difícil en este fragmento. Interpreto «le».

tres votos: alusión a los votos de pobreza, castidad y obediencia, representados en los tres nudos del cordón franciscano; pero voto es también 'juramento o blasfemia' (Léxico). Calderón, El alcalde de Zalamea: «Ayer todo erais reniegos, / por vidas, votos y pesias; / y hoy estáis más apacible» (ed. cit., vv. 1125-1127).

36 regla: es alusión a la aprobación de la Regla franciscana por el papa Inocencio III (San Buenaventura, Leyenda Mayor 3,10).

38 camaradas: «Germ. Pandilla, reunión, generalmente de maleantes» (Léxico); mesa también es voz de germanía: «En el juego, mesa donde se juegan grandes cantidades de dinero» (Léxico). En la lectura religiosa, en cambio, 'camaradas' son compañeros y 'mesa', «el sagrado manjar del cuerpo de Nuestro Señor Jesucristo Sacramentado, que liberalmente nos franquea en la mesa del altar» (Autoridades).

40 las cuerdas: potro de tormento en el que se le hacían desencajar lentamente los huesos al reo. Quevedo, Carta de Escarramán a la Méndez: «Hallé dentro a Cardeñoso, / hombre de buena verdad, / manco de tocar las cuerdas / donde no quiso cantar» (Un Heráclito cristiano, ed. Schwartz-Arellano, n. ${ }^{\circ} 286$, vv. 25-28). Rodrigo Herrera, Castigar por defender: «Ella me ha de volver loca / si aprieta mucho la cuerda» (vv. 1062-1063, en Comedias burlescas, III, ed. Ignacio Arellano. Calderón, El alcalde de Zalamea: «DON LOPE. Denle dos tratos de cuerda. / REBOLLEDO. ¿Tras... qué me han de dar, señor? / DON LOPE. Tratos de cuerda. / REBOLLEDO. Yo hombre / de aquestos tratos no soy» (ed. cit., vv. 815-818).

41 Cantó [...] de plano: es formulilla empleada por Cáncer en otras jácaras. 'Cantar' es voz germanesca: «Confesar; declarar un reo en el tormento los delitos que ha cometido y a veces los que no ha cometido» (Léxico). En estos versos se hace patente la irreverencia del poeta con el santo, también conocido como 'el cantor de Dios'.

42 vuelta: «Germ. En el tormento de cordel la vuelta que da el verdugo a las clavijas apretando las cuerdas al cuerpo del reo» (Léxico); pero también 'media vuelta' es «breve u cortísima diligencia en alguna cosa» (Autoridades). Quevedo, jácara A una dama señora, hermosa por lo rubio: «Ir de tormento a un estribo, / hecho verdugo con potro, / dando vueltas a mi dama, / es muy pesado negocio» (Poesía original completa, ed. cit, 854, vv. 81-84).

43 partido: lo mismo que 'trato, resolución'. Tirso, Cigarrales de Toledo. «Fuele forzoso (por la necesidad que de presente tenía) aceptar el partido, que para la hambre no hay pan malo» (ed. Vázquez Fernández, p. 292). Salas Barbadillo, El gallardo Escarramán: «El partido no acepto, no me agrada» (en La tradición Escarramanesca en el teatro del Siglo de Oro, ed. cit., v. 501).

44 jerga: «Tela gruesa y rústica [...] Tómase también por cualquier especie de paño grosero, sea de lana, de pelo u cáñamo» (Autoridades). Alusión al sayal franciscano, pero también a la vestidura de los condenados y a 'jerigonza', por lo de cantar. Rojas, La Celestina: «iVaya con nosotros llanto, acompáñenos soledad, síganos desconsuelo, visítenos tristeza, cúbranos luto y dolorosa jerga!» (ed. cit., p. 325).

45 brazos: de «tener brazos. Por favorecedores» (Correas). Crítica a la venalidad de la justicia; pero también 'fuerza'. Esta cuarteta es copia fiel de la última de otra jácara dedicada al mismo santo y que vemos en las Obras varias de Cáncer (primera edición de 1651, fol. 66r.).

46 justiciado: aféresis de 'ajusticiado'. Es vulgarismo.

48 borriquito: los castigos afrentosos de azotes o vergüenza pública eran precedidos de un paseo en ese animal. Quevedo, romance «Hagamos cuenta con pago»: «Y sin mirar la justicia / que era título de libro, / me vistieron el jubón / que le entallan los borricos» (Poesía original completa, ed. cit., 753, vv. 65-68). 
Vida y milagros de san Francisco

$$
\text { Quintillas de Ciego. }
$$

Un ciego soy que he venido

a cantar en esta tropa

al varón más escogido.

Atención, señores, pido,

que hoy ha de haber brava sopa.

Contaré la vida, pues, de aquel santo que descubre llagas en manos y en pies, y que cae no sé en qué mes a cuatro días de otubre.

Fueron sus padres, en cuanto a sangre, gente de honor, y su caudal era tanto, que a no ser Francisco santo, él lo pasara mejor.

Desde su infancia sencilla vio que Cristo era salud, camino y norte que brilla, y esto le sirvió de asilla para seguir la virtud.

Su padre le persuadía al noble trato que él tiene; y, diciéndoselo un día, le respondió: Usté se viene con linda mercadería.

Ricas telas de Milán les daba a los afligidos, y andaban muy sin afán vestidos de tafetán cojos, mancos y tullidos.

Su padre, como esto vio y que en roballe era listo, como tanto lo sintió, de casa un día le echó y él se fue con Jesucristo.

1 ciego: personaje que se ganaba la vida cantando o vendiendo romances o coplas de ciego por calles y plazas.

5 brava sopa: la comida que se repartía a los mendigos en los conventos. Generalmente consistía en un poco de caldo y unos mendrugos de pan.

19 asilla: 'pretexto' y 'asa pequeña'.

24 Usté: la pérdida de la dental sonora era síntoma de lengua popular. 
Viendo Francisco esta acción, se fue a Roma con trabajo, y allí con resolución fundó cierta Religión, que se dirá más abajo.

Siempre los brazos abiertos se ejecutaba en piedades; y eran sus ruegos tan ciertos, que resucitaba muertos de todas enfermedades.

A un niño dio vida un día, $y$, burlando de la parca, dejó el arca en que yacía; y allí se vio que tenía los milagros en el arca.

Halló un pozo en un camino y el agua clara que brota, con el auxilio divino, la convirtió toda en vino y fue cosa muy devota.

Poníale Lucifer una y otra tentación para obligalle a caer; y el demonio, a mi entender, llevaba mala intención.

Forma de mujer tomó una noche y entró a velle con mil galas que fingió, mas conocióle en que no llevaba cruz en el muelle.

Murió, por fin de la historia, nuestro santo esclarecido, y hoy está, por más memoria, gozando de eterna gloria a donde Dios es servido.

39 Religión: la orden mendicante de los "Hermanos Menores", que hizo aprobar en Roma por el papa Inocencio III.

55 devota: 'devota' y 'de bota'. Calambur.

65 muelle: adorno que solían llevar las mujeres pendiente de la cintura.

70 a donde Dios es servido: en 'lugar indefinido'. Es una expresión. 
Vida y milagros de san Francisco

En quintillas de ciego

En Asís avecindados para en uno estaban dos, marido y mujer honrados, que no dirían a Dios sino que estaban casados.

Deseaban tiernamente un hijo, que les nació; y su madre, que es prudente, al tiempo que le parió, dicen que estuvo presente.

Creció el muchacho en edad, dando indicio superior de su mucha santidad; mas de la virginidad nadie le cayó en la flor.

A su padre le robaba para dar a los mendigos, y aunque su real guardaba, en él Francisco le daba como en real de enemigos.

Viendo su padre que no bastaba el castigo blando, en su casa le encerró, y Francisco, aunque calló, se quedó un poco rezando.

Con pecho compadecido, su madre caritativa libró a su hijo querido porque en fin le había parido, como dijimos arriba.

Una enfermedad le dio que desbaratara un risco, y tan al cabo llegó, que Francisco prometió ser fraile de san Francisco.

2 para en uno estaban dos: de la expresión popular «para en uno son los dos», de los matrimonios bien avenidos.

15 flor: «Significa también la entereza virginal» (Aut).

20 como en real de enemigos: «Dar en ello, como en real de enemigos. Con brío» (Correas).

25 rezando: 'orando' y 'gruñendo'.

31 enfermedad: alusión a unas fiebres gravísimas que padeció en 1203, año en el que decidió cambiar de modo de vida. 
Fundar religión quería, y llegándose a informar, halló que el Papa tenía para hacer lo que él quería buleto particular.

Guardaba del lobo immundo, que las ovejas persigue, todo el rebaño del mundo, Inocencio, no el segundo, sino el otro que se sigue.

Confirmó su religión el Papa con los demás, que así para una ocasión no es mala confirmación mientras no se puede más.

Llegábanse por momentos muchos al tosco sayal, y ocupaban sus conventos hombres de lindos talentos, pero de poco caudal.

$\mathrm{Y}$ eran tantos a porfía los que se alistaban gratos en su Orden cada día, que Francisco no podía conocelles los zapatos.

Todo el día se empleaba en contemplación severa, y el rato que le vagaba, dos mil milagros obraba, yo no sé de qué manera.

El tentador pretendía ver a Francisco caer, y mil lazos le ponía, porque entonces no tenía el demonio más que hacer.

Una noche a verle entró en mujer desfigurado, y tanto le persuadió,

\footnotetext{
40 buleto: diminutivo de bula. Alusión a la fundación de la orden mendicante que hizo aprobar en Roma por el papa Inocencio III.

41 immundo: 'inmundo'; es la forma etimológica, del latín IMMUNDUS. En el XVII no existía la colisión «NM», sustituida siempre por «MM».

46 Confirmó su religión: 1209, año del nacimiento de la Orden franciscana.

68 lazos: 'tentaciones'.
} 
que el santo, por sí o por no, no consintió en el pecado.

Sobre la nieve felice, huyendo otra vez del Malo, que en virtud contradice, se arrojó, como quien dice, pobreza, mas con regalo.

Dando temor al profundo, y abriendo al cielo camino, murió el santo sin segundo, después que en aqueste mundo vivió como un capuchino.

Ver su cuerpo singular nadie llegó a merecello, que un Pontífice sin par nunca lo pudo alcanzar, aunque reventó por vello.

\section{REFERENCIAS BIBLIOGRÁFICAS}

\section{Textos utilizados para la anotación}

ALONSO HERNÁNDEZ, José Luis. Léxico del marginalismo del Siglo de Oro. Salamanca: Universidad de Salamanca, 1976. Filosofía y Letras, 99.

CALDERÓN DE LA BARCA, Pedro. El alcalde de Zalamea. Escudero Baztán, Juan M. (ed. crítica). Madrid: Iberoamericana, 1998. Biblioteca Áurea Hispánica, 1.

—. La dama duende. Antonucci, Fausta (ed.). Barcelona: Crítica, 1999. Biblioteca Clásica, 69.

CÁNCER Y VELASCO, Jerónimo de. Obras varias. Madrid: Diego Díaz de la Carrera, 1651.

CASTRO, Guillén de. Las mocedades del Cid. Arata, Stefano (ed.).Barcelona: Crítica, 1996. Biblioteca Clásica, 59.

CERVANTES, Miguel de. Don Quijote de la Mancha. Ed. del Instituto Cervantes. Rico, Francisco (dir.). Barcelona: Crítica, 1998, 2 vols. Biblioteca Clásica, 50.

Comedias burlescas del Siglo de Oro. Tomo III. ed. del GRISO. Arellano, Ignacio. (dir.). Madrid: Iberoamericana, 2002. Biblioteca Áurea Hispánica, 16.

MOLINA, Tirso de. El burlador de Sevilla y convidado de piedra. Rodríguez López-Vázquez, Alfredo (ed.). Madrid: Cátedra, 1989. Letras Hispánicas, 58.

—. Cigarrales de Toledo.Vázquez Fernández, Luis (ed.). Madrid: Castalia, 1996. Clásicos Castalia, 216.

74 por sí o por no: 'por si acaso'.

76 nieve felice: el sustantivo parece tomarse en su sentido literal, aunando en lógica correspondencia la paradoja literaria a la humana.

83 sin segundo: 'sin par que lo igualase'.

85 capuchino: religioso de san Francisco, por alusión al capucho puntiagudo con que se cubrían la cabeza.

88 Pontífice: posible alusión a la macabra visita a la tumba del santo del papa Nicolás $\mathrm{V}$ en 1449 o al mismo celo de los vecinos de Asís, quienes enterraron el cuerpo sobre una colina ante las posibles tentativas de robo. 
PINTO, Elena di. La tradición Escarramanesca en el teatro del Siglo de Oro. Madrid: Iberoamericana, 2005. Biblioteca Áurea Hispánica, 35.

QUEVEDO, Francisco de. Un Heráclito cristiano, canta sola a Lisi y otros poemas. Schwartz, Lía; Arellano, Ignacio (eds.). Barcelona: Crítica,1998. Biblioteca Clásica, 62.

-. Poesía original completa. Blecua, J.M. (ed.). Barcelona: Planeta 1981. Clásicos Universales Planeta, 22.

—. Los sueños. Arellano, I (ed.). Madrid: Cátedra, 1991. Letras Hispánicas, 335.

—. La vida del Buscón. Cabo Aseguinolaza, Fernando (ed. crítica). Barcelona: Crítica, 1993. Biblioteca Clásica, 63.

REAL ACADEMIA ESPAÑOLA. Diccionario de Autoridades. Edición facsímil. Real Academia Española, 1726-1739, 6 vols., $3^{\text {a }}$ reimpresión. Madrid: Gredos, 1976, 3 vols. Biblioteca Románica Hispánica. V. Diccionarios, 3.

-. Diccionario de la lengua española. $21^{\mathrm{a}}$ ed. Madrid: Espasa Calpe, 1992, 2 vols.

ROJAS, Fernando de. La Celestina. Lobera, F.; Serés, G.; Díaz-Mas, P.; Mota, C.; Arzálluz, R.; y Rico, F. Barcelona: Crítica, 2000. Biblioteca Clásica, 20.

VEGA CARPIO, Lope. El Caballero de Olmedo. $20^{\mathrm{a}}$ edición. Rico, Francisco (ed.). Madrid: Cátedra, 2003, Letras Hispánicas, 147.

Vida y hechos de Estebanillo González, La. Carreira, Antonio; Cid, Jesús Antonio (eds.). Madrid: Cátedra, 1990. Letras Hispánicas, 309 y 312.

Fecha de recepción: 30 de julio de 2007

Fecha de aceptación: 20 de enero de 2008 